\title{
ПЕРСПЕКТИВИ ВПРОВАДЖЕННЯ У НАВЧАЛЬНИЙ ПРОЦЕС КРЕДИТНО-МОДУЛЬНОЇ СИСТЕМИ ДЛЯ СТУДЕНТІВ ЗАОЧНОЇ ФОРМИ НАВЧАННЯ НА КАФЕДРІ МЕДИЧНОЇ БІОЛОГІЇ І МЕДИЧНОЇ ГЕНЕТИКИ
}

Н. В. Довганич

ДВНЗ “Івано-Франківський національниймедичнийуніверситет”

\section{PROSPECTS FOR THE IMPLEMENTATION OF THE CREDIT- MODULAR SYSTEM IN EDUCATIONAL PROCESS FOR PART-TIME STUDENTS AT THE DEPARTMENT OF MEDICAL BIOLOGY MEDICAL GENETICS}

N. V. Dovganych

\author{
SHEI "Ivano-Frankivsk National Medical University"
}

\begin{abstract}
Розглянуто питання організації впровадження у навчальний процес кредитно-модульної системи з біології 3 основами генетики для студентів заочної форми навчання фармацевтичного факультету. Внесено пропозиції щодо втілення нових інформаційних технологій у навчальний процес та поглиблення викладання предмета, що дозволяє розширити експеримент зі здійснення дистанційного навчання та контролю знань студентів заочної форми навчання. Аргументовано необхідність розробляти нові методи і форми взаємодії викладача і студента, стимулювати самостійну навчальну діяльність, що є однією з умов Болонського процесу.
\end{abstract}

This article deals with the problem of credit-modular system of educational process organization for part-time students on biology with basis of genetics at the Pharmacy Department. There has been made a motion as to implementation of new information technologies in the educational process and extending subject teaching. It will result in expanding the experiment of distance learning and academic performance rating of part-time students. The need to develop new methods and forms of interaction between teacher and student has been reasoned. Self instruction has been encouraged, which is one of the conditions of the Bologna process.

Вступ. Розвиток фармацевтичного бізнесу створив останнім часом значний попит на висококваліфікованих фахівців з вищою освітою, як денної, так і заочної форми навчання [1]. Це пов'язано з тим, що в сучасних умовах для вільного просування людини в освітньому просторі необхідно забезпечити максимальну гнучкість і різноманітність форм освіти, важливих в умовах ринкової економіки. Тому в системі вищої освіти в усьому світі неминуче відбуваються процеси розвитку заочного, дистанційного та інших форм навчання без відриву від роботи [4]. Для реалізації даної проблеми вкрай необхідною є підготовка кваліфікованих медичних кадрів. Вирішити це завдання допоможе втілення у навчальний процес кредитно-модульної системи для студентів заочної форми навчання на кафедрі медичної біології.

(c) Н. В. Довганич
Основна частина. Метою є втілення у навчальний процес кредитно-модульної системи для студентів заочної форми навчання з біології з основами генетики, із впровадженням нових інформаційних технологій у навчальний процес.

Біологія з основами генетики, як фундаментальна дисципліна, $є$ теоретичною базою для студентів фармацевтичного факультету, викладання якої повинно базуватися на таких критеріях: наступності та професійної спрямованості.

Саме з таких позицій на кафедрі медичної біології і медичної генетики Івано-Франківського національного медичного університету переглянуто навчально-методичний комплекс, доповнено відповідними матеріалами, які забезпечать реалізацію основних позицій Болонської системи.

Розроблено нову навчальну програму, яка $є$ складовою частиною державного стандарту освіти та 
впровадження кредитно-модульної системи оцінки знань студентів. Особливість програми полягає також у специфіці професійної підготовки майбутніх клінічних провізорів, орієнтованих на знання взаємовідношень лікарські засоби - людина. Окрім фундаментальної загальнобіологічної підготовки, студенти опановують навички, які необхідні для практичної і науково-дослідної роботи клінічного провізора [2].

Структурована навчальна програма на один модуль, де розглядаються питання, присвячені клітині, як структурно-функціональній одиниці живого, вивченню закономірностей спадковості і мінливості у людини, які базуються на основах загальної генетики; вагоме місце в цьому розділі займають спадкові хвороби людини, механізми їх виникнення, методи діагностики та профілактики; життєві процеси і закономірності на популяційно-видовому рівні; життєві цикли паразитів, взаємовідносини між паразитами і організмом людини, шляхи зараження, патогенний вплив на організм людини, методи діагностики, принципи лікування та профілактики паразитарних захворювань.

Вагоме місце у підготовці майбутніх фармацевтів займає методична робота. Незважаючи на те, що за останнє десятиріччя на кафедрі накопичено цінний досвід, продовжується подальша робота з підготовки оригінальних навчальних і контролюючих матеріалів у вигляді тестів, професійних ситуаційних завдань та орієнтовних дій їх вирішення. У зв'язку зі змінними вимогами удосконалюються методичні матеріали для викладачів і студентів, найголовніше, методичні рекомендації з організації самостійної роботи. Викладачами кафедри були розроблені нові методичні рекомендації для проведення практичних занять з біології з основами генетики.

На сайті університету знаходяться питання, тести, задачі, адаптовані до типової навчальної програми в межах 15 \%, які використовуються на практичних заняттях та підсумковому модульному контролі, методичні рекомендації для практичних занять, для виконання контрольних робіт та самостійної роботи студентів.

На лекціях особливу увагу приділяють питанням, які можуть стати базою для майбутньої професійної діяльності. При розгляді лекції “Молекулярні основи спадковості. Реалізація спадкової інформації” звертається увага на роль коротких mi PHК та si PHК, які можуть використовуватися для зниження експресії патологічних генів.У лекції “Екологія паразитів” розглядаються питання будови, особливості життєвих циклів паразитів, способи зараження, застосування специфічної та неспецифічної профілактики.
На практичних заняттях проводиться індивідуальне усне опитування за теоретичними питаннями на основі рекомендованої літератури, які включені до методичних розробокз відповідних тем, тестовий контроль, розв'язування ситуаційних задач за темою заняття.

Основною формою роботи студентів-заочників у міжсесійний період є виконання ними контрольних робіт, передбачених навчальним планом, які виконуються кожним студентом самостійно, тому на сайті університету поміщено методичні розробки, за допомогою яких студенти можуть ознайомитись із завданнями, які виносяться на контрольну роботу.

Контрольна робота студентів включає 10 питань по 6 балів кожне з них: п’ять теоретичних завдань та п’ять задач. Максимальна кількість балів, яку може отримати студент при виконанні роботи, - 60, мінімальна кількість - 30 .

Метою контрольної роботи є поглиблення, узагальнення і закріплення знань студентів з навчальної дисципліни і вироблення вміння самостійно працювати 3 навчальною літературою.

Особливе місце у підготовці майбутніх фармацевтів займає використання новітніх технологій на лекціях та практичних заняттях. Викладачами кафедри створено банк зображень макро- і мікропрепаратів 3 медичної паразитології, які демонструють на практичних заняттях на телеекранах, встановлених у навчальних кімнатах. Для якісного засвоєння матеріалу викладачі використовують новітні технології викладання предмета, а саме: відеофільми за тематикою практичних занять (методи вивчення спадковості людини, спадкові хвороби, медична протозоологія, гельмінтологія та арахноентомологія).

Для кращого засвоєння тем, які винесені на самостійне вивчення, студенти користуються електронними ресурсами університетської бібліотеки.

Розвиток дистанційного навчання нині обмежений істотними проблемами, такими, як: проблема комунікації в Україні, де рівень технології помітно відстає від розвинених західних країн, питання якості курсів, програмного забезпечення та освітніх стандартів. Ці обставини, на наш погляд, не дозволяють поставити систему дистанційного навчання на противагу очному або заочному видам. На порядку денному може стояти лише використання його елементів у традиційних освітніх моделях. Заочне навчання регулюється і організовується державою на основі єдиних освітніх стандартів і вимагає обов'язкового проведення аудиторного навчання [3].

Висновки: 1. Впровадження кредитно-модульної системи у навчальний процес для студентів заочної 


\section{ВДОСКОНАЛЕННЯ ВИЩОЇ МЕДИЧНОЇ ОСВІТИ}

форми навчання на кафедрі медичної біології і медичної генетики дозволить забезпечити фундаментальну підготовку клінічного провізора та набуття практичних навичок для професійної діяльності майбутнього фармацевта.

2. Технічний прогрес і розвиток засобів комунікацій призвели до того, що проблему забезпеченості сту-

\section{Списоклітератури}

1. Колесник Ю. М. Болонський процес та якість освіти / Ю. М. Колесник, Ю. М. Нерянов // Медична освіта. - 2005. - № 2. - С. 38-40.

2. Пряхін О. Р. Досягнення та перспективи розвитку заочної фармацевтичної освіти у Запорізькому державному медичному університеті / О. Р. Пряхін, О. О. Портна // Запорож. мед. журн. -2006. - № 2. - С. 178-179.

3. Стан та перспективи розвитку дистанційних технологій освіти на заочному відділенні фармацевтичного факуль- дентів комп'ютерами і виходом в Інтернет майже вирішено. Технічної забезпеченість навчальнометодичного процесу дозволяє розширити експеримент зі здійснення дистанційного навчання та контролю знань студентів заочної форми навчання.

тету / О. Р. Пряхін, О. А. Рижов, О. О. Портна, О. І. Андросов // Актуал. питання фармац. та мед. науки та практики : зб. наук. ст. - Запоріжжя : Вид-во ЗДМУ, 2006. - Вип. XV, T. 3. - C. 51-52.

4. Збірник нормативних документів з питань організації заочного навчання у вищих навчальних закладах України / за ред. М. Ф. Дмитриченка. - К. : Український центр духовної культури, 2002. - 244 с. 